\title{
How Does Organizational Climate Contribute to Job Satisfaction and Commitment of Agricultural Extension Personnel in New Valley Governorate, Egypt?
}

\author{
Ahmed M. Diab ${ }^{1}$, Hend M. Diab ${ }^{2}$, Dina H. Emam ${ }^{3}$
}

\begin{abstract}
This research aimed to 1) explore the organizational climate of the agricultural extension in New Valley Governorate, 2) explore the status quo of job satisfaction and commitment of extension personnel in the New Valley Governorate, and 3) investigate the impact of agricultural extension organizational climate on job satisfaction and commitment of extension personnel. Data were collected using the questionnaire form during January to February 2021, from a sample of 25 Extension personnel representing $37.3 \%$ of their total number in New Valley Governorate (67 Personnel). Frequencies, mean, standard deviation and stepwise regression analysis were used for data presentation and analysis. Findings revealed that the respondents' perceptions overall mean score of the organizational climate reached $\mathbf{6 8 . 2 6 \%}$ of the total score, their job satisfaction is $\mathbf{7 3 . 6 \%}$ of the total score, and their organizational commitment reached $68.4 \%$ of the total score. Findings also show that the variable of "Efficiency" contribute to the interpretation of $19.6 \%$ and $57.7 \%$ of variance of the Job Satisfaction and Employees' Commitment, respectively. Other variable influenced the Job Satisfaction is "Outward Focus" which contributed $37 \%$ of the explanation of the variance of the overall Job Satisfaction. Results also revealed that the variable of " Clarity of Organizational Goals" is contributed to the interpretation of $10.7 \%$ of variance of the Job Satisfaction. Based on the previous results the null hypotheses numbers $10,12,13$, and 31 could be rejected, while the remaining null hypotheses couldn't be rejected.
\end{abstract}

Key words: organizational climate, job satisfaction, job commitment, agricultural extension

\section{INTRODUCTION}

The Organizational Climate (OC) is the shared perceptions of organizational policies, practices, and procedures (Reichers and Schneider, 1990). It can be determined by the individuals' perceptions of their workplaces, as reflected by personal values and psychological desires (James et al., 2007; McMurray et al., 2010). It is the process that is assumed to be a major force in influencing employee behavior (McMurray et al., 2010). Permarupan, et al., (2013) stated that the organizational climate represents the condition of the organization's culture, the most common management issue facing the organization nowadays is search for creative flexible work environment that promotes job satisfaction and innovation. While, Moran and Volkwein (1992) defined the concept of organizational climate from the perspective of organizational characteristics including a) the perceptions that employees share on autonomy, trust, cohesiveness, support, appreciation, innovation and fairness that exist in their organization; b) it is produced from interactions of organization's members; c) it serves as a basic stance for employees' understandings of certain situations; d) it describes the norms and attitudes of an organizational culture, and e) it influences individual's work behaviors.

Many studies have formulated indicators of organizational climate most of which are related. Among these are the 17-factor model for organizational climate measure (OCM) was developed and tested with a large sample of employees drawn from 55 manufacturing organizations, it consists of the following factors (Patterson, et al., 2005): 1) Autonomy: designing jobs in ways which give employees wide scope to enact work, 2) Integration: the extent of interdepartmental trust and cooperation, 3) Involvement: employees have considerable influence over decision-making, 4) Supervisory Support: the extent to which employees experience support and understanding from their immediate supervisor, 5) Training: a concern with developing employee skills, 6) Welfare: the extent to which the organization values and cares for employees, 7) Formalization: concern with formal rules and procedures, 8) Tradition: the extent to which established ways of doing things are valued, 9) Innovation \& Flexibility: the extent of encouragement and support for new ideas and innovative approaches and orientation toward change, 10) Outward Focus: the extent to which

DOI: 10.21608 /asejaiqjsae.2021.193596

${ }^{1}$ Department of Rural Sociology \& Agricultural Extension, Faculty

of Agriculture, New Valley University, Kharga, Egypt,

E-mail: a.diab@nvu.edu.eg

${ }^{2}$ Department of Rural Sociology \& Agricultural Extension, Faculty

of Agriculture, Ain Shams University, Cairo, Egypt,

E-mail: hend_moukhtar@agr.asu.edu.eg

${ }^{3}$ Department of Rural Sociology \& Agricultural Extension, Faculty

of Agriculture, Cairo University, Cairo, Egypt,

E-mail: dina.emam@agr.cu.edu.eg.

Received August 05, 2021, Accepted, September 08, 2021. 
the organization is responsive to the needs of the customer and the marketplace in general, 11) Reflexivity: a concern with reviewing and reflecting upon objectives, strategies, and work processes, in order to adapt to the wider environment, 12) Clarity of Organizational Goals: concern with clearly defining the goals of the organization, 13) Efficiency: the degree of importance placed on employee efficiency and productivity at work, 14) Effort: how hard people in organizations work towards achieving goals, 15) Performance Feedback: the measurement and feedback of job performance, 16) Pressure to Produce: the extent of pressure for employees to meet targets, and 17) Quality: the emphasis given to quality procedures.

The OCM scales which are likely to map onto the Competing Values quadrants are (Patterson, et al., 2005): 1) Human Relations: comprising, Involvement, Autonomy, Supervisory Support, Integration, Welfare, Training, and Effort; 2) Internal Process: Formalization and Tradition; 3) Open Systems: Reflexivity, Innovation \& Flexibility, and Outward Focus; and 4) Rational Goal: Clarity of Organizational Goals, Pressure to Produce, Quality, Performance Feedback, and Efficiency.

The organizational climate is vital to determine factor of organizational outcomes, several characteristics of organizational climate have been associated with work group cooperation, supervisor support, performance responses, personnel's participation (Lafta, et al., 2016). Higher satisfaction with work domains among extension professionals positively impact employees' job satisfaction and job performance as well as their commitment (Windon, 2019).

Employees' job satisfaction refers to a positive emotion experienced by an individual in reaction to the individual's job and task after comparing the similarities and differences between real job experiences and earlier expectations related to one's job (Locke \& Latham, 1990; Tsai, 2014; Gaunya, 2016). Job satisfaction of the employees is an important indicator of the health of the organization, it greatly facilitates the task of administrators because it creates promising conditions for the overall progress of the organization (Mishra, 2005; Debnath \& Saravanan, 2014). Recent studies on job satisfaction has intensive on the job itself or the work climate as the key means of increasing satisfaction. The main argument is that, if jobs or work climate are developed to provide a more desirable work environment, an increase in job satisfaction will result (Jyoti, 2013).

AbdelGhany (2014) stated that, Weiss et al. (1967) separate job satisfaction into internal and external satisfaction. Internal satisfaction consists of all the factors that have direct correlation with job satisfaction as follows: 1) Ability utilization (the chance to do something that makes use of employee's abilities), 2) Achievement (the feeling of accomplishment he get from the job), 3) Activity (being able to keep busy all the time, 4) Advancement (the chances for advancement on the job, 5) Compensation (pay and the amount of work he do), 6) Coworkers (the way that coworkers get along with each other's), 7) Creativity (the chance to try employee's methods of doing the job), 8) Independence (the chance to work alone on the job), 9) Moral values (the ability to do things that don't go against conscience), 10) Social service (the chance to do things for other people, 11) Social status (the chance to be somebody in the community, and 12) Working conditions. External satisfaction consists of all the other factors which indirectly correlate with job satisfaction as follows: 1) Authority (the chance to tell other people what to do), 2) Policies and practices (the way policies are put into practice), 3) Recognition (the praise employee get for doing a good job), 4) Responsibility (the freedom to use his own judgment), 5) Security (the way his job provides for steady employment), 6) Supervision- human relations (the way that boss handles his men), 7) Supervision- technical (the competence of the supervisor in making decisions), and 8) Variety (the chance to do different things from time to time).

The commitment is defined as the strength of an individual's identification with the goals of an organization (Permarupan, et al., 2013). It is an attitude of having a strong desire to remain in a certain organization, strive according to the organization wishes, and belief in the acceptance of organizational values and goals (Sugiarto, 2018).

According to Allen \& Meyer (1990) and Labrague et al., (2018) the organizational commitment is the emotional relationship between employees and organizations which consists of affective commitment, normative commitment, and ongoing commitment. Meyer et al., (1993) mentioned the three components of commitment as follows:

- Affective commitment: the employee's emotional attachment to identification with an involvement in the organization. Employees with a strong affective commitment will remain in the organization because they want to.

- Continuance commitment: the awareness of the costs associated with leaving the present organization. Employees whose commitment is continuance will remain in the organization because they have to.

- Normative commitment: the feeling of obligations to the organization based on one's personal norms and values. Employees whose commitment to the organization is said to be of the normative type 
remains in the organization simply because they believe they ought to.

Employee performance is the key factor of organizational success. Performance relates to compensation and job satisfaction and job commitment. Employees who are satisfied with and committed to their jobs will have positive feelings, former researchers used organizational climate variables as a dimension that can affect employee job satisfaction and commitment (Sugiarto, 2018).

In previous study, Diab and Emam (2021a) have studied the impact of workplace characteristics profile on extension personnel's empowerment, they found that the extension personnel level of empowerment could be actively increased through changing factors of workplace characteristics, especially the "task standardization", the "standardization of roles, controlling harassment, and communication. In another study of Diab and Emam (2021b) which aimed to study the re-engineering of administrative processes within agricultural extension, it was found that it is necessary to support re-engineering processes in order to improve the organizational climate for agricultural extension, which affects institutional effectiveness.

\section{Objectives}

This research thus fills gaps in the organizational climate (OC) literature by examining the connections between OC's factors and employee's satisfaction and commitment. It aimed to:

1. explore the organizational climate of the agricultural extension in New Valley Governorate

2. explore the status quo of job satisfaction and commitment of extension personnel in the New Valley Governorate

3. investigate the impact of agricultural extension organizational climate on job satisfaction and commitment of extension personnel

\section{METHODOLOGY}

\section{Methodology}

The Organizational Climate Measure (OCM) developed by Patterson and his colleagues (Patterson et $a l .$, 2005) was used to measure the organizational climate for agriculture extension organization in New Valley. The measure consists of 17 subscales (with 82 statements), it divided in to four main quadrants: human relations, internal process, open systems, and rational goal (more details of number of statements and maximum scores for subscales and quadrants are illustrated bellow in tables $3 \& 4$ ). Respondents were asked to decide their responses based on scale of
1=Definitely false, 2=Mostly false, 3=Mostly true, 4=Definitely true.

Job satisfaction was indexed using the Minnesota satisfaction questionnaire (Weiss et al., 1967), which consists of 20-items containing two dimensions: internal satisfaction (12 items) and external satisfaction (8 items). Respondents were asked to give their opinions on each statement on a 5-points Likert scale started from 1 very dissatisfied to 5 very satisfied. The maximum score of the overall satisfaction reached 100 scores (60 for the internal satisfaction, and 40 for external satisfaction).

The employees' commitment was measured using the scale developed by Meyer et al., (1993). The scale consists of the six-subscales (with 6 statement for each). Three subscales representing (affective, continuance and normative) commitment to occupation and the other three representing (affective, continuance and normative) commitment to the organization. Respondents were asked to give their opinions on each statement on a 5-points Likert scale started from 1 strongly disagree to 5 strongly agree. The maximum score of the occupational commitment reached 90 scores (30 for each subscale) and the maximum score of the organizational commitment reached 90 scores (30 for each subscale). The overall score of the employees' commitment reached 180 scores.

Data were collected using the questionnaire form during January to February 2021, from a sample of 25 Extension personnel representing 37.3\% of their total number in New Valley Governorate (67 Personnel). Frequencies, mean, standard deviation, and stepwise regression analysis were used for data presentation.

In order to achieve the third objective of the study, a theoretical hypothesis was formulated stating that: "The organizational climate has a strong effect on the employees' job satisfaction and their commitment". Based on this, thirty-six statistical hypotheses were formulated, stating that: "The organizational climate subscales have no impact on employees' job satisfaction and each of the commitment subscales. Hypotheses number 1 to 18 are for Job satisfaction subscales .And Hypotheses number 19 to 36 are for Employees' Commitment subscales as shown in table 1 .

Table 2 presents the distribution of extension personnel according to their personal characteristics; data shows that the majority aged 50 years and above, hold B.Sc. of agricultural sciences, with rural origin, and have less than 10 years of work experience in agricultural extension. 
Table 1 Matrix of the study's hypotheses

\begin{tabular}{lcc}
\hline OCM's Subscales & Job Satisfaction & Employees' Commitment \\
\hline Autonomy & 1 & 19 \\
Integration & 2 & 20 \\
Involvement & 3 & 21 \\
Supervisory Support & 4 & 22 \\
Training & 5 & 23 \\
Welfare & 6 & 24 \\
Formalization & 7 & 25 \\
Tradition & 8 & 26 \\
Innovation \& Flexibility & 9 & 27 \\
Outward Focus & 10 & 28 \\
Reflexivity & 11 & 29 \\
Clarity of Organizational Goals & 12 & 30 \\
Efficiency & 13 & 31 \\
Effort & 14 & 32 \\
Performance Feedback & 15 & 33 \\
Pressure to Produce & 16 & 34 \\
Quality & 17 & 35 \\
\hline Overall OCM & 18 & 36 \\
\hline
\end{tabular}

Table 2 Distribution of extension employees according to their personal characteristics $(\mathrm{N}=25)$

\begin{tabular}{llc}
\hline Characteristics & Category & Frequency \\
\hline Age & Below 50 years old & 7 \\
& 50 years old and above & 18 \\
\hline Educational attainment & Agricultural secondary school certificate & 9 \\
& Bachelor of Agriculture & 16 \\
\hline \multirow{2}{*}{ Origin } & Rural & 21 \\
& Urban & 4 \\
\hline Years of work experience in extension & Less than 10 years & 14 \\
& 10 years and above & 11 \\
\hline
\end{tabular}

Source: the study's findings

\section{RESULTS AND DISCUSSION}

\section{Organizational climate of the Agricultural Extension in the New Valley}

Table 3 presents mean scores for each of the organizational climate subscales. As indicated in the table, subscales mean scores are less than the overall average levels for ten components of the OCM scale while the remaining seven components are above the overall average scores. The table show that the respondents' perceptions overall mean score of the organizational climate reached 223.9 which represents $68.26 \%$ of the total score.

The table revealed also that "innovation and flexibility" received the highest score among the seventeen components of OCM (81.9\% of the maximum score) followed by the component "reflexivity" $(81 \%)$; this implies that the climate of agricultural extension organization is encouraging and supporting new ideas and innovative approaches and has an orientation towards change it also entails reviewing and reflecting upon objectives, strategies, and work processes, in order to adapt to the wider environment.

Results indicate also that the agricultural extension climate supports employees' experience and understanding from their immediate supervisor in addition to the extent to which the extension organization values and cares for employees as the subscales of "supervisory support" and " welfare" received highly rank of OCM amounted to $79.5 \%$ and $71.9 \%$, respectively.

Moreover, findings show the emphasis that given by organizational climate to "quality" procedures (78.4\%). The high score of the "tradition" subscale (73.4\%) implies that the extent to which established ways of doing things are valued. Findings also revealed that there is a clear defining of the goals of the extension organization as revealed form the high score $(72 \%)$ of the "clarity of organizational goals" subscale. In contrast, the "formalization" of extension organization 
received $66.3 \%$ of the maximum score, this implies that extension employees perceived that the extension organization is relying moderately on formal rules and procedures.

The extension organization's climate has medium extent of pressure on employees to meet targets as the "pressure to produce" subscale represented $65.3 \%$ of the maximum score, the job design give the employees medium wide scope to enact wok as the "autonomy" subscale received $63 \%$ of the maximum score. About "outward focus" it received $62.8 \%$ this implies the extension organization has medium extend to respond to the needs of the customer and the marketplace in general.

The results also show the relatively low average of job performance of the extension employees, as is evident from the low score $(62.5 \%)$ obtained by the "performance feedback", this results go on line with that obtained by the score of "effort" subscale which received $66.5 \%$ of the maximum score. This may be due to the decreased interest of the extension organization in providing trainings to its employees, as the "training" subscale received only $61.6 \%$ of the maximum score.
Findings show also the relative decrease in the level of employees' participation in the decision-making process and the low extent of interdepartmental trust and cooperation where the "involvement" and "integration" subscales received only $60 \%$ and $65.5 \%$ of the maximum score, respectively. As for the low degree of importance placed on employee efficiency and productivity at work where the "efficiency" subscale got the lowest percentage ( $45.9 \%$ of the maximum score). This may be due to the decreased interest of the extension organization in providing trainings to its employees in addition to low of "Performance Feedback" and "Pressure to Produce" $(62.5 \%$ \& $65.25 \%$, respectively).

Figure 1 displays the Radar diagram of the gaps between maximum and mean scores of extension OCM subscales. The gaps are calculated by subtracting the mean scores from the maximum score (of each subscale). Findings revealed that the wide three gaps are found in the subscales of "efficiency", "involvement" and "training" which mean that some efforts should be taken to decrease those gaps. While the narrowest three gaps appear in "innovation \& flexibility", "reflexivity" and "supervisory support"

Table 3 Means and percentages of extension personnel's perceptions of the OCM's subscales

\begin{tabular}{|c|c|c|c|c|c|c|}
\hline \multirow{2}{*}{ OCM subscales } & \multirow{2}{*}{$\begin{array}{l}\text { No of } \\
\text { items }\end{array}$} & \multirow{2}{*}{$\begin{array}{l}\text { Maximum } \\
\text { score }\end{array}$} & \multirow{2}{*}{$\begin{array}{c}\text { Std. } \\
\text { Deviation }\end{array}$} & \multicolumn{2}{|c|}{ Mean } & \multirow{2}{*}{ Rank } \\
\hline & & & & Value & Percentage & \\
\hline Autonomy & 5 & 20 & 1.39 & 12.60 & 63.00 & 12 \\
\hline Integration & 5 & 20 & 1.37 & 13.10 & 65.50 & 10 \\
\hline Involvement & 6 & 24 & 2.04 & 14.40 & 60.00 & 16 \\
\hline Supervisory Support & 5 & 20 & 2.43 & 15.90 & 79.50 & 3 \\
\hline Training & 4 & 16 & 1.31 & 9.85 & 61.56 & 15 \\
\hline Welfare & 4 & 16 & 0.89 & 11.50 & 71.88 & 7 \\
\hline Formalization & 5 & 20 & 1.94 & 13.25 & 66.25 & 9 \\
\hline Tradition & 4 & 16 & 2.73 & 11.75 & 73.44 & 5 \\
\hline Innovation \& Flexibility & 6 & 24 & 1.90 & 19.65 & 81.88 & 1 \\
\hline Outward Focus & 5 & 20 & 2.98 & 12.55 & 62.75 & 13 \\
\hline Reflexivity & 5 & 20 & 1.85 & 16.20 & 81.00 & 2 \\
\hline Clarity of Organizational Goals & 5 & 20 & 1.39 & 14.40 & 72.00 & 6 \\
\hline Efficiency & 4 & 16 & 1.50 & 7.35 & 45.94 & 17 \\
\hline Effort & 5 & 20 & 1.13 & 13.30 & 66.50 & 8 \\
\hline Performance Feedback & 5 & 20 & 1.40 & 12.50 & 62.50 & 14 \\
\hline Pressure to Produce & 5 & 20 & 1.23 & 13.05 & 65.25 & 11 \\
\hline Quality & 4 & 16 & 1.50 & 12.55 & 78.44 & 4 \\
\hline Overall OCM & 82 & 328 & 8.03 & 223.90 & 68.26 & - \\
\hline
\end{tabular}

Source: The study's findings 


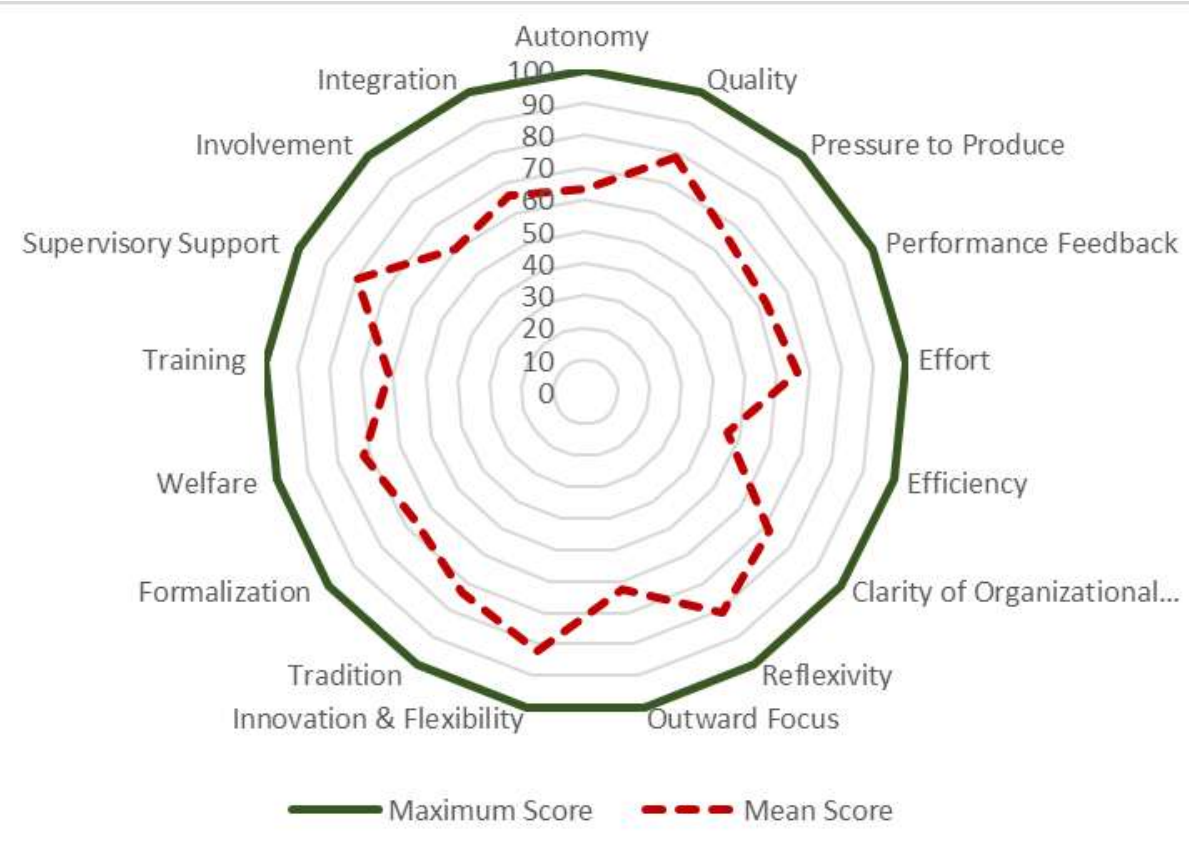

Figure 1. Radar Chart displays of gap between maximum and mean scores of agricultural extension organizational climate measure (OCM) subscales

Source: the study's findings.

Regarding the OCM's quadrants, findings in table 4 show the mean and maximum scores of each of the four quadrants, two of the quadrants have scores above the average (open systems and internal process), the other two quadrants have below average scores (Human Relations and Rational Goal).

The quadrant "open systems" which includes subscales of "innovation \& flexibility", "outward focus", and "reflexivity" received the highest value of average with 48.4 score which represent $75.6 \%$ of the maximum score, that may due to the high values obtained by subscales of "innovation \& flexibility" and "reflexivity" as they occupied the first to ranks among the OCM's subscales. This emphasizes the agricultural extension organization's readiness, change and innovation, where norms and values are associated with growth, resource acquisition, creativity and adaptation. Similarly, the quadrant of "internal process" received the second rank with percentage of $69.4 \%$. In the "Internal Process" (formalization and tradition) emphasis on the classic bureaucracy or stability, where the effects of environmental uncertainty are ignored or minimized, and resources are efficiently used.

The quadrant of "Human Relations" (comprising, involvement, autonomy, supervisory support, integration, welfare, training, and effort) received below overall average score (mean $=77.35$ which represent $66.7 \%$ of the maximum score of the quadrant) this emphasizes the shortages in well-being, growth and commitment of the community of workers within the extension organization. This implies that the climate of extension organization has norms and values associated against belonging, trust, and cohesion, as well as shortages in training and human resource development. About the lowest score, the quadrant of "rational goal" (comprising, clarity of organizational goals, pressure to produce, quality, performance feedback, and efficiency), received the last position by $65.3 \%$ of the maximum score, this implies the low productivity and goal achievement of extension organization.

Figure 2 displays the Radar diagram of the gaps between maximum and mean scores of extension OCM quadrants. Findings revealed that the wider two gaps are found to be in the quadrants of "human relations", and "rational goal" which mean that the Extension Organization should exert some efforts that would help decrease those gaps. While the narrower two gaps are within the "open systems" and "internal process" quadrants. 
Table 4. Means and percentages of extension personnel's perceptions of the OCM's quadrants

\begin{tabular}{|c|c|c|c|c|c|c|c|}
\hline \multirow{2}{*}{ OCM's quadrants } & \multirow{2}{*}{$\begin{array}{c}\text { No. of } \\
\text { subscales }\end{array}$} & \multirow{2}{*}{$\begin{array}{l}\text { No of } \\
\text { items }\end{array}$} & \multirow{2}{*}{$\begin{array}{l}\text { Maximum } \\
\text { score }\end{array}$} & \multirow{2}{*}{$\begin{array}{c}\text { Std. } \\
\text { Deviation }\end{array}$} & \multicolumn{2}{|c|}{ Mean } & \multirow{2}{*}{ Rank } \\
\hline & & & & & Value & Percentage & \\
\hline Open Systems & 3 & 16 & 64 & 3.70 & 48.40 & 75.63 & 1 \\
\hline Internal Process & 2 & 9 & 36 & 2.71 & 25.00 & 69.44 & 2 \\
\hline Human Relations & 6 & 29 & 116 & 3.75 & 77.35 & 66.68 & 3 \\
\hline Rational Goal & 6 & 28 & 112 & 2.48 & 73.15 & 65.31 & 4 \\
\hline Overall OCM & 17 & 82 & 328 & 8.03 & 223.90 & 68.26 & - \\
\hline
\end{tabular}

Source: The study's findings

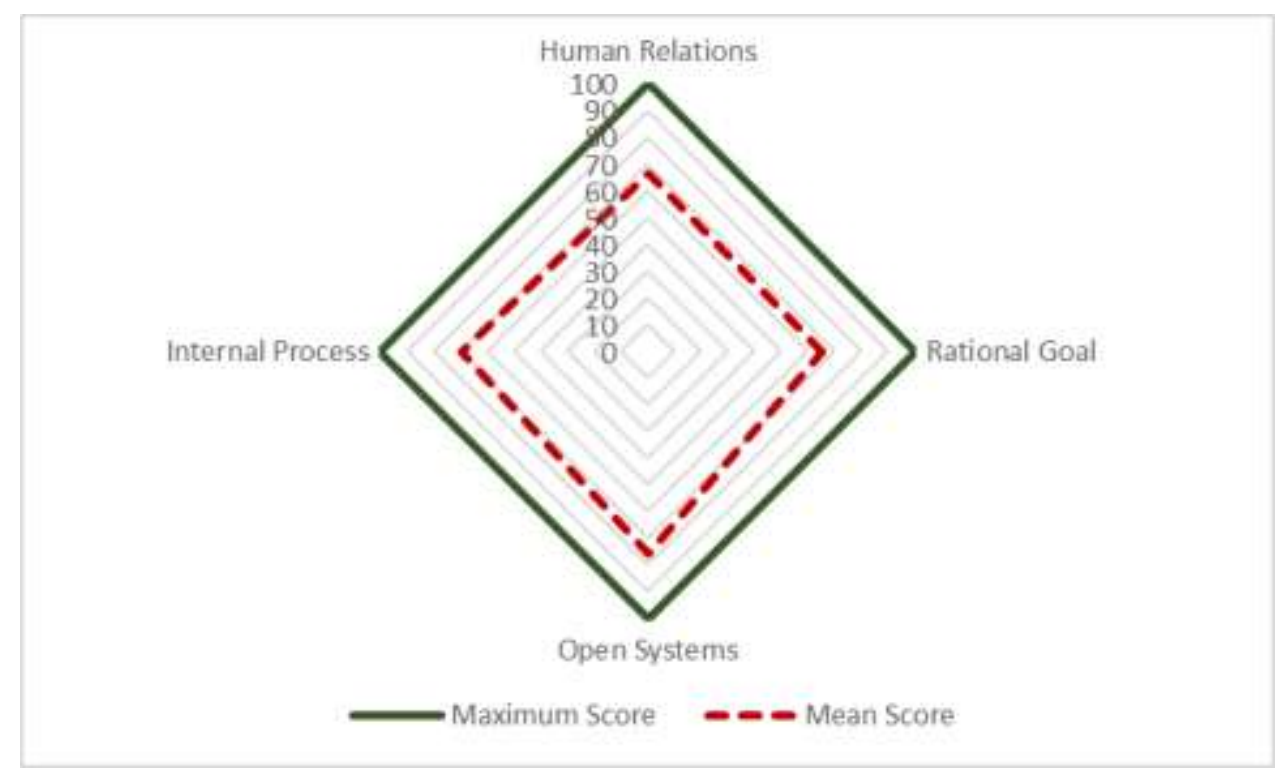

Figure 2. Radar Chart displays of gap between maximum and mean scores of agricultural extension organizational climate measure (OCM) quadrants

Source: the study's findings.

\section{Extension Personnel's Job Satisfaction}

Table 5 represents the mean scores and percentages for extension employees' responses to the job satisfaction scale. The figures in the table show that the overall average value of job satisfaction reached 73.6 or $73.6 \%$ of the total score; which implies that extension employees are slightly satisfied with the job they perform. The table also reveals that the scores are above average for the subscale of "external satisfaction" (comprising of: authority, policies and practices, recognition, responsibility, security, supervision and variety). This subscale received the higher score (74.4\% of the maximum score), while the "internal satisfaction" subscale (comprising of: ability utilization, achievement, activity, advancement, compensation, coworkers, creativity, independence, moral values, social service, social status and working conditions) received a percentage of 73.1 the maximum score.

Figure 3 displays the gaps between maximum and mean scores of employees' satisfaction. Findings in the figure shows that a more than a quarter gap appear in both internal and external satisfaction, which mean that the Extension Organization should exert some efforts that would help decrease those gaps.

Table 5 Means and percentages of extension personnel's Job Satisfaction subscales

\begin{tabular}{|c|c|c|c|c|c|c|}
\hline \multirow{2}{*}{ Job Satisfaction subscales } & \multirow{2}{*}{$\begin{array}{l}\text { No of } \\
\text { items } \\
\end{array}$} & \multirow{2}{*}{$\begin{array}{c}\text { Maximum } \\
\text { score }\end{array}$} & \multirow{2}{*}{$\begin{array}{c}\text { Std. } \\
\text { Deviation }\end{array}$} & \multicolumn{2}{|c|}{ Mean } & \multirow{2}{*}{ Rank } \\
\hline & & & & Value & Percentage & \\
\hline Internal Satisfaction & 12 & 60 & 6.36 & 43.85 & 73.08 & 2 \\
\hline External Satisfaction & 8 & 40 & 5.15 & 29.75 & 74.38 & 1 \\
\hline Overall Job Satisfaction & 20 & 100 & 11.25 & 73.60 & 73.60 & - \\
\hline
\end{tabular}

Source: The study's findings 


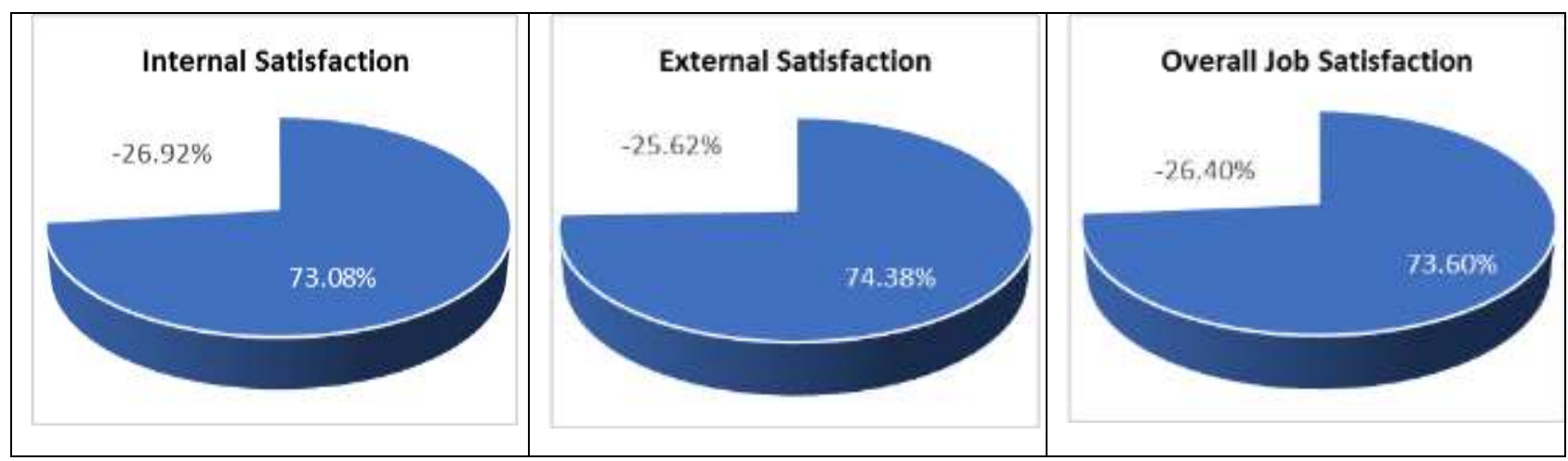

Figure 3. extension employees' job satisfaction gaps

Source: the study's finding

\section{Extension Personnel's Commitment}

Commitment is the attitude of having a strong desire to remain in the organization, strive according to its wishes, and belief in the acceptance of its values and goals, table 6 presents mean scores of the agricultural extension employees' commitment. As indicated in the table, findings revealed that the total score of organizational commitment reached 61.5 which represent $68.4 \%$ of the maximum score. This imply the medium commitment of extension personnel to their organization. Findings indicate also that respondents express below average "affective commitment to the organization, ACS-ORG" (mean score is 17.8 which represent $59.3 \%$ of the maximum score), and display above average "continuance commitment to the organization (CCS-ORG) and normative commitment to the organization (NCS-ORG)" as the mean scores represent $70.8 \%$ and $75 \%$ of the maximum scores, respectively.

Regarding the occupational commitment, findings revealed that the mean of total score of occupational commitment reached 65.78 score which represented $65.78 \%$ of the maximum score. This finding implies that respondents have occupational commitment more than the organizational commitment. Similarly, respondents express below average "affective commitment to the occupation, ACS-OCC" (mean score is 17.6 which represent $85.8 \%$ of the maximum score), and display above average "continuance commitment to the occupation (CCS-OCC) and normative commitment to the occupation (NCS-OCC)" as the mean scores represent $66.5 \%$ and $72 \%$ of the maximum scores, respectively.

Figure 4 show the gaps between maximum and mean scores of employees' commitment. Findings revealed that the component of "Affective Commitment" has the widest gaps (with percentage of $-40.7 \%$ and -
$41.2 \%)$, followed by the component of "Continuance Commitment" $(-29.2 \% \&-33.5 \%)$ and finally the component of " Normative Commitment" (-25\% \& $28 \%$ ) for the organizational and the occupational commitment respectively, which mean that the Extension Organization should exert some efforts that would help decrease those gaps.

\section{Impact of Organizational Climate on Job Satisfaction and Employees' Commitment}

In order to determine the effect of each of the dimensions of OCM on job satisfaction and employees' commitment The Stepwise multiple regressions analysis was used. The findings in table 7 show that the job satisfaction as dependent variable is affected by three of the studied dependent variables. In this model, the " $\mathrm{f}$ " value is significant at 0.01 level. Accordingly, the variable of "Efficiency" which contribute to the interpretation of $19.6 \%$ of variance of the $J o b$ Satisfaction. This means that unit of changes of standard deviation of the Efficiency explain 0.196 of unit change in standard deviation of the Job Satisfaction. Other variable influenced the Job Satisfaction is "Outward Focus" which contributed $37 \%$ of the explanation of the varience of the overall Job Satisfaction. Findings also revealed that the variable of "Clarity of Organizational Goals" is contributed to the interpretation of $10.7 \%$ of variance of the Job Satisfaction.

Findings show also that the variable " Efficiency" explain about $57.7 \%$ of variance on "Employees' Commitment. This means that unit of changes of standard deviation of the Efficiency explain 0.58 of unit change in standard deviation of the Employees' Commitment. Based on the previous results it could be reject the null hypotheses numbers $10,12,13$, and 31 while the remaining null hypotheses couldn't be rejected. 
Table 6 Means and percentages of extension personnel's commitment subscales

\begin{tabular}{|c|c|c|c|c|c|c|}
\hline \multirow{2}{*}{ Employees' Commitment } & \multirow{2}{*}{$\begin{array}{l}\text { No of } \\
\text { items }\end{array}$} & \multirow{2}{*}{$\begin{array}{l}\text { Maximum } \\
\text { score }\end{array}$} & \multirow{2}{*}{$\begin{array}{c}\text { Std. } \\
\text { Deviation }\end{array}$} & \multicolumn{2}{|c|}{ Mean } & \multirow{2}{*}{ Rank } \\
\hline & & & & Value & Percentage & \\
\hline Affective commitment to the organization & 6 & 30 & 2.31 & 17.80 & 59.33 & 3 \\
\hline Continuance commitment to the organization & 6 & 30 & 3.48 & 21.25 & 70.83 & 2 \\
\hline Normative commitment to the organization & 6 & 30 & 3.27 & 22.50 & 75.00 & 1 \\
\hline Total Commitment to the Organization & 18 & 90 & 6.59 & 61.55 & 68.39 & - \\
\hline Affective commitment to the occupation & 6 & 30 & 2.48 & 17.65 & 58.83 & 3 \\
\hline Continuance commitment to the occupation & 6 & 30 & 3.05 & 19.95 & 66.50 & 2 \\
\hline Normative commitment to the occupation & 6 & 30 & 3.68 & 21.60 & 72.00 & 1 \\
\hline Total Commitment to the Occupation & 18 & 90 & 6.64 & 59.20 & 65.78 & - \\
\hline Overall Personnel's Commitment & 36 & 180 & 12.10 & 120.75 & 67.08 & \\
\hline
\end{tabular}

Source: The study's findings

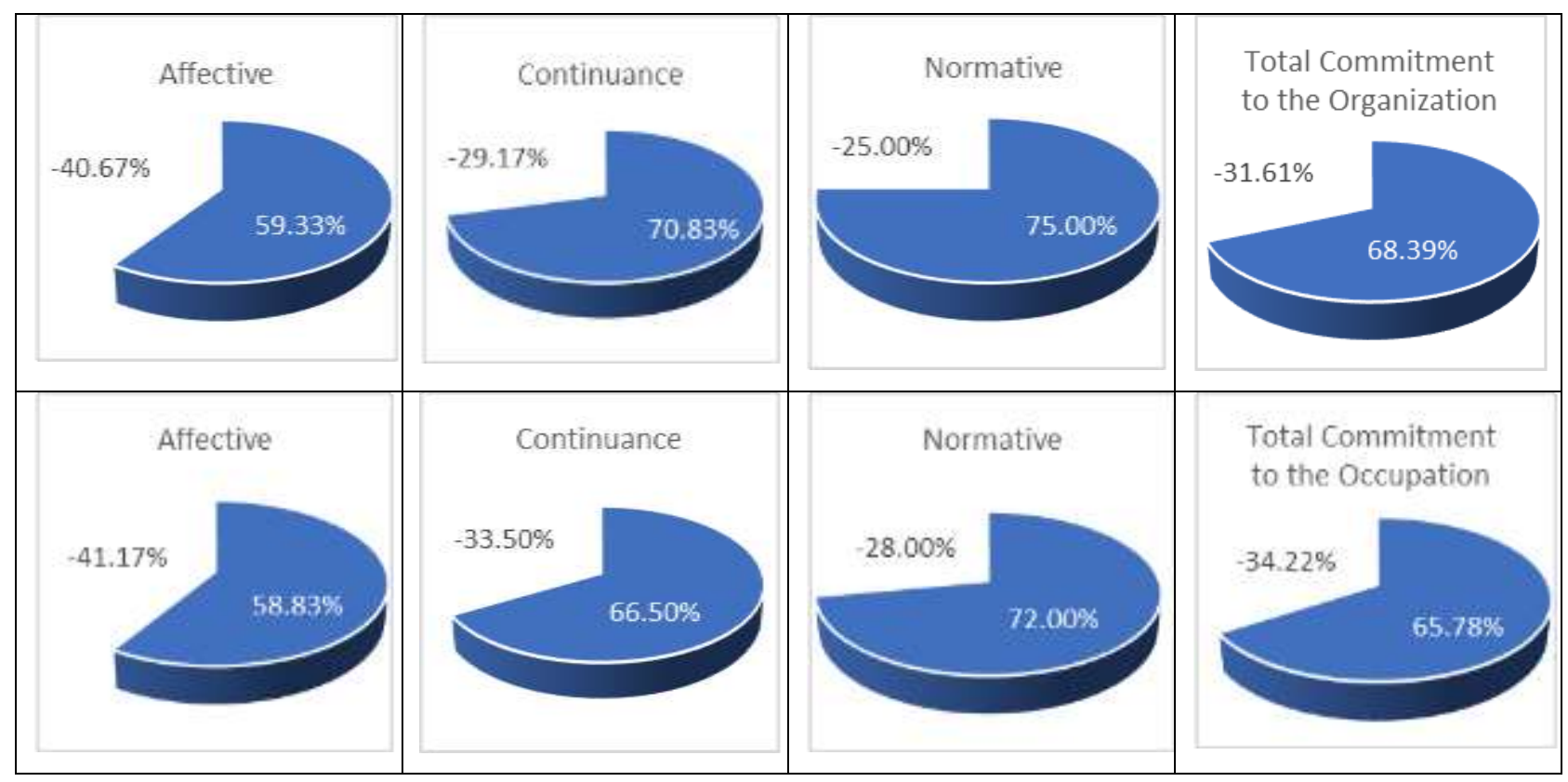

Figure 4. extension employees' commitment gaps

Source: the study's finding

Table 7 Impact of organizational climate on job satisfaction and employees' commitment

\begin{tabular}{|c|c|c|c|c|c|c|}
\hline Dependent variables & $\begin{array}{c}\text { Analiyzing } \\
\text { steps }\end{array}$ & $\begin{array}{c}\text { Independent variables } \\
\text { (Organizational Climate } \\
\text { Measures) }\end{array}$ & $R^{2}$ & $\begin{array}{l}\text { Adjusted } \\
R^{2}\end{array}$ & $\begin{array}{c}\text { \%of } \\
\text { Varience } \\
\text { Interpretation }\end{array}$ & F Value \\
\hline \multirow[t]{3}{*}{ Job Satisfaction } & Step 1 & Efficiency & 0.238 & 0.196 & 19.6 & $5.64^{*}$ \\
\hline & Step 2 & Outward Focus & 0.612 & 0.566 & 37.0 & $13.39^{* *}$ \\
\hline & Step 3 & $\begin{array}{l}\text { Clarity of Organizational } \\
\text { Goals }\end{array}$ & 0.725 & 0.673 & 10.7 & $14.06^{* *}$ \\
\hline Employees' Commitment & Step 1 & Efficiency & 0.599 & 0.577 & 57.7 & $26.88^{* * *}$ \\
\hline
\end{tabular}




\section{CONCLUSIONS}

The current study focuses on organizational climate in relation to job satisfaction and organizational commitment. The OCM was used to identify characteristics of the organizational climate, Job satisfaction was indexed using the Minnesota satisfaction questionnaire and the employees' commitment was measured using the Meyer et al., scale. The findings indicated that the variable of "Efficiency" contribute to Job Satisfaction and Employees' Commitment, and variables of "Outward Focus" and "Clarity of Organizational Goals" contribute to job satisfaction. Based on the previous results it could be concluded that employees' job satisfaction and commitment could be enhanced through promoting the efficiency, Outward Focus and Clarity of Organizational Goals as dimensions of the climate of agricultural extension organization. Consequently, the study recommends spending more efforts in promoting the organizational climate of agricultural extension in order to insure its organizational effectiveness.

\section{REFERENCES}

AbdelGhany, M.M.M. 2014.Workplace Characteristics, Job Satisfaction and Organizational Commitment of Extension Personnel in the New Valley Governorate. J. Agric. Econom. and Social Sci., Mansoura Univ., 5(6): 961-975.

Allen, N.J. and J.P. Meyer. 1990. The measurement and antecedents of affective, continuance and normative commitment to the organization. Journal of Occupational Psychology, 63(1), 1-18.

Debnath, A. and R. Saravanan.2014.Job satisfaction and job autonomy of extension personnel of the public agricultural extension organization in Tripura state of north-east India. International Journal of Development Research. 4(8): 1643-1650.

Diab, Ahmed M. and Dina H. Emam.2021a. Examining the Effects of workplace characteristics on empowerment of the agricultural extension employees in New Valley governorate, Egypt. Alex. Sci. Exch. J. 42(2):413-422.

Diab, Ahmed M. and Dina H. Emam.2021b. The relationship between agricultural knowledge management and the reengineering of administrative processes within the Agricultural Extension Organization in Egypt. Scientific Journal of Agricultural Sciences. 3(2).

Gaunya, C.R.2016. Organizational Climate as a Determinant of Job Satisfaction among Public Sector Employees in Kisii County, Kenya Journal of Resources Development and Management. Vol.23: 47-53.

James, L.R. and A.P. Jones. 1974. Organizational climate: A review of theory and research. Psychological Bulletin, (81):1096-1112.
Jyoti, J. 2013. Impact of Organizational Climate on Job Satisfaction, Job Commitment and Intention to Leave: An Empirical Model. Journal of Business Theory and Practice, 1(1): 66-82.

Labrague, L. J., D.M. McEnroe - Petitte; K. Tsaras; J.P. Cruz, P.C. Colet and D.S. Gloe.2018.Organizational commitment and turnover intention among rural nurses in the Philippines: Implications for nursing management. International Journal of Nursing Sciences, 5(4): 403-408.

Lafta, A.H., N. Man, J. M. Salih, B. Abu Samah, N.M. Nawi and R.N.R. Yusof.2016. A Need for Investigating Organizational Climate and Its Impact on the Performance. European Journal of Business and Management. 8(3): 136-142.

Locke, E.A. and G.P. Latham. 1990. Work motivation and satisfaction: Light at the end of the tunnel, A Journal of the Association for Psychological Science. 1(4):240-246.

McMurray, A.J., A. Pirola-Merlo, J.C. Sarros and M.M. Islam. 2010. Leadership, climate, psychological capital, commitment, and Wellbeing in a non-profit organization, Leadership \& Organization Development Journal, 31(5): 436-457.

Meyer, J., N. Allen and C. Smith. 1993. Commitment to organizations and occupations: Extension and test of a three-component conceptualization, Journal of Applied Psychology, 78(4): 538-551.

Moran, E.T. and J.F. Volkwein. 1992.The cultural approach to the formation of organizational climate. Human Relations, 45(1):19-47.

Patterson, M.G., M.A. West, V. j. Shackleton, J. F. Dawson, R. Lawthom, S. Maitlis, D. 1. Robinson and A.M. Wallace. 2005.Validating the organizational climate measure: links to managerial practices, productivity and innovation. J. Organiz. Behav, 26: 379-408.

Permarupan, P.Y., R.A. Saufi, R.S.R. Kasimc, and B. Balakrishnan. 2013. The Impact of Organizational Climate on Employee's Work Passion and Organizational Commitment. Procedia - Social and Behavioral Sciences 107: $88-95$.

Reichers, A.E. and B. Schneider. 1990. Climate and culture: an evolution of constructs, in Schneider, B. (Ed.), Organizational Climate and Culture, Jossey-Bass, San Francisco, CA.

Sugiarto, I. 2018. Organizational climate, organizational commitment, job satisfaction, and employee performance. Diponegoro International Journal of Business.1(2): 112120.

Tsai, C. 2014. The Organizational Climate and Employees' Job Satisfaction in the Terminal Operation Context of Kaohsiung Port. The Asian Journal of Shipping and Logistics, 30(3): 373-392.

Weiss, D., R. Davis, G. England and L. Lofquist.1967.Manual for Minnesota satisfaction questionnaire, University of Minnesota, Industrial Relations Center. 119 p.

Windon, Suzanna R. 2019. Predictors of Job Satisfaction Among Extension Program Assistants. Journal of Agricultural Education, 60(3): 232-245. 
الملخص العزبي - - الما

كيف يسهم المناخ التظيمي في الرضا والالتزام الوظيفي للعاملين بالإرشاد الزراعي في محافظة الوادي

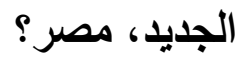

$$
\text { أحمد محمد دياب وهند مختار دياب و دينا حسن إمام }
$$

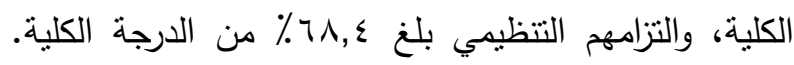

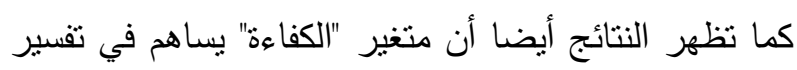

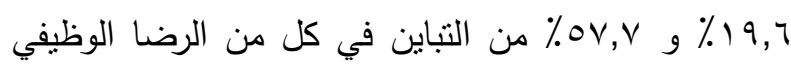
والإلتزام التتظيمي للعاملين بالإرشاد الزراعي على التى التوالي.

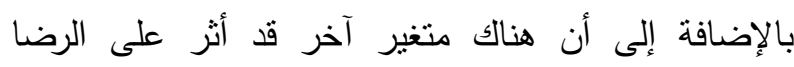

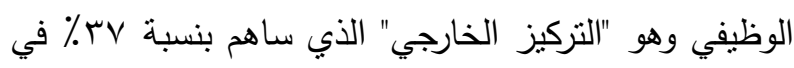
تفسير التباين في الرضا الوظيفي للعاملين. كما أظهرت

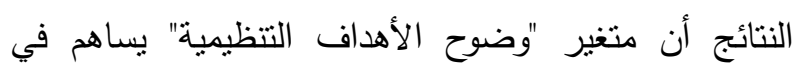
تفسير V, • 1\% من التباين في الرضا الوظيفي للمبحوثين.

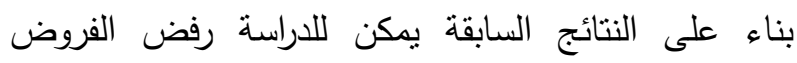

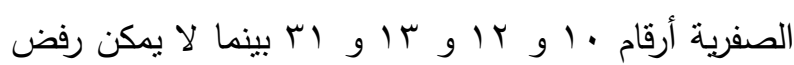
الفروض الصفرية المتنقية. الكلمات الدالة: الدناخ التتظيمي، الرضا الوظيفي، الإلتزام

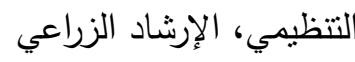

يهدف هذا البحث إلى () استكثاف المناخ التتظيمي

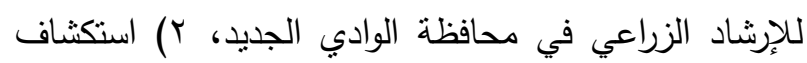

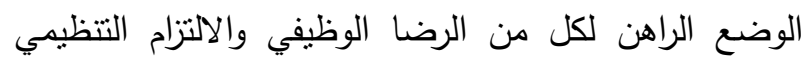
للعاملين بالإرشاد الزراعي بححافظة الوادي الجديد، و ؟ r)

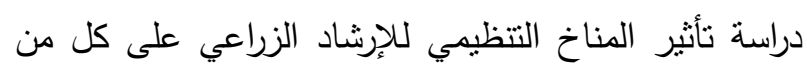

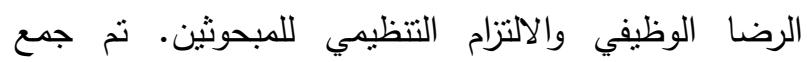
البيانات باستخدام إستمارة الاستيان خلال شهر يناير

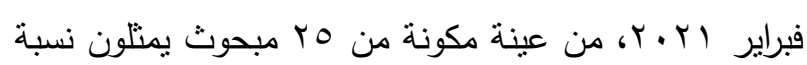

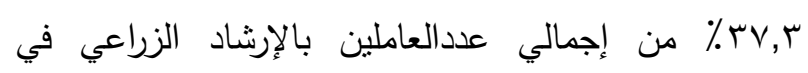
محافظة الوادي الجديد (TV فرد). تم استخدام التكرارات والمتوسط الحسابي والانحراف المعياري وتحليل الانحدار

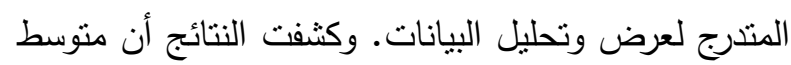

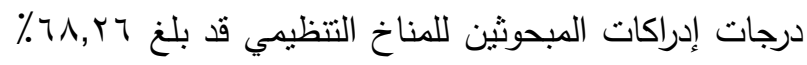

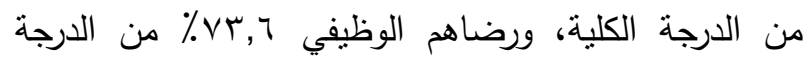

